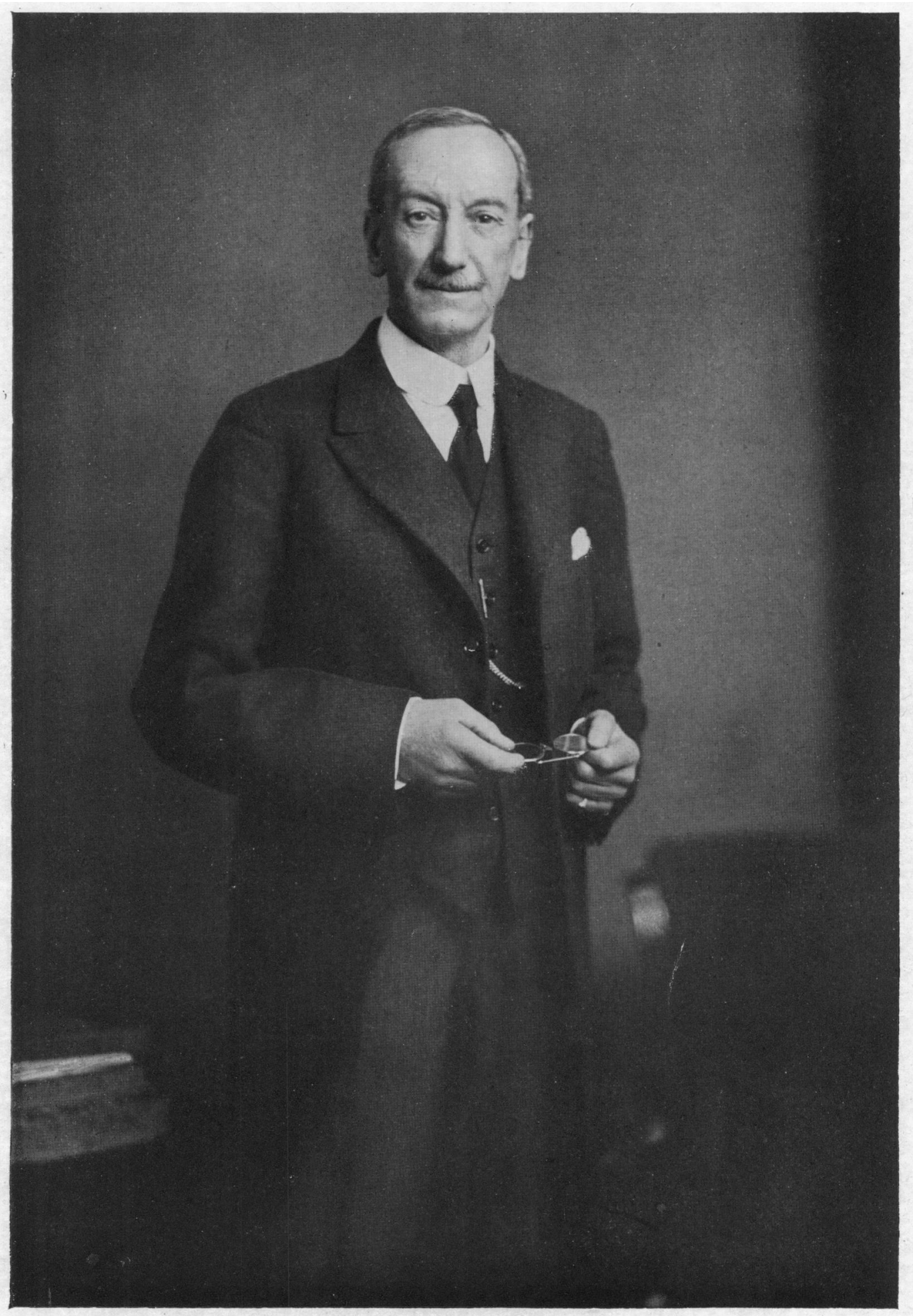

JOHN COWAN

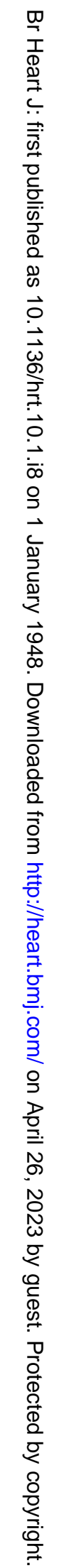




\section{JOHN COWAN}

John Cowan sprang from a long line of Glasgow doctors many of whom had held posts in the University. His father, J. B. Cowan, had been Regius Professor of Materia Medica, and his grandfather, Robert Cowan, had been Professor of Medical Jurisprudence, and both had been Physicians to the Glasgow Royal Infirmary.

Born in 1870 he was educated at Fettes, King's College (Cambridge), and Glasgow University. He qualified at Cambridge in 1895 and held resident appointments in the Western Infirmary, the Children's Hospital, and the Glasgow Fever Hospital.

In 1900 he served in the South African War as physician to the Scottish National Red Cross Hospital. On his return to Glasgow he joined the junior clinical staff of the Western Infirmary and was assistant to Professor Samson Gemmell. At the same time he worked with Robert Muir in the pathological department and published papers in the Journal of Pathology on fibrosis of the heart.

In 1906 he was appointed Physician to the Royal Infirmary and finding much to be done to raise the standard of work in that hospital he spent most of his day in the wards. All through his term of office as physician, Cowan attended almost daily at 9 a.m. and spent most of the morning in the wards. $\mathrm{He}$ was a slow worker, but every case was investigated with meticulous care and he exacted the same care and industry from his house physicians and assistants.

Stimulated by the work of Wenckebach and Mackenzie, and with the pathological knowledge culled from Robert Muir, Cowan acquired one of the first polygraphs, and from 1909 onwards he published papers on the arrhythmias in the Quarterly Journal of Medicine and Heart.

Then came the 1914-18 War, and Cowan served in the Egyptian Expeditionary Force as consulting physician (1916-19).

After the war Cowan returned to his work in the Royal Infirmary and to consulting practice in the West of Scotland. At this time the Ministry of Pensions appointed consultants in cardiovascular diseases in various regions in the British Isles, and Cowan was appointed to the West of Scotland. These consultants held conferences twice a year in London, and these gatherings of men interested in the same cardiovascular problems were the forerunners of the Cardiac Club.

In the first volume of the British Heart Journal Cowan has given an account of the birth of the Cardiac Club, and he was the first secretary (1922-5) and was chiefly instrumental in formulating our simple rules and regulations. Up to the last war he was most regular in attendance and " just before his death he had received the current list of members and perused it thoroughly" (Miss Cowan). Though chiefly interested in cardiovascular disease a full list of his publications would show the variety of his clinical interests. His Diseases of the Heart was a notable contribution based on personal experience, and was expanded in later editions when he had the collaboration of his friend, Willie Ritchie.

He gave the George Gibson Lecture at the R.C.P., Edinburgh, in 1926, and the St. Cyres Lecture at the National Hospital for Diseases of the Heart in 1930.

He was Physician in Scotland to King George V, King Edward VIII, and King George VI (1925-40). In 1923 he was appointed Gentleman, the King's Body Guard for Scotland, and this select and honourable post pleased him immensely.

At the beginning of the last war he began to do less work, and eventually retired to Kilmalcolm, Renfrewshire, where he died on August 15, 1947, aged 77 years. His latter years had been much saddened by the sudden death of his wife and the tragic deaths of his two sons. His only daughter had always been a great friend and was a constant solace to him in his declining years.

His two friends, - Geoffrey B. Fleming and Archibald Harrington have sent us sympathetic and appreciative impressions of Cowan and his work in Glasgow.

Fleming says: "Cowan soon became recognized as one of the leading ' heart men' in Glasgow. I think he was the first to install an electrocardiograph in his house. Although he made full use of this instrumental method he always insisted that they could not replace clinical examination. No one was more thorough in his examination of his patients and his case records show the extraordinary conscientiousness of his work. Every case in his wards, whether of particular interest to him or not, 
had to be most carefully examined and recorded. $\mathrm{He}$ was the most conscientious man I have ever known.

"As a teacher I think he was at his best with a small number of students at the bedside. His systematic lectures owing to his rather peculiar mannerisms, would have been difficult to follow had it not been for his admirable printed notes.

"As a man he was extremely reserved and on this account it was only those who knew him well who appreciated his true worth. His loyalty to his friends was sometimes quixotic. He never spoke hardly of those he disliked; I think he disregarded or avoided them. He had many interests outside medicine-a keen and expert angler and an ardent philatelist. He was very interested in modern history. At the time of his death he had just completed a monograph on the Glasgow School of Medicine, largely based on the records he had of his medical ancestors. I think he undertook this work in order to keep his mind active after his retirement from practice. He could never be idle."

Harrington says: "When he came to the Royal, much required to be done, and he did it in the face of a good deal of opposition. He spent most of the day in the wards, exhausting most of his staff! He got things done in the end, as he always did, and put the wards on sound and modern lines.

"In his earlier days he was not a very popular teacher. His delivery was difficult to follow at times, but he gradually overcame this, and by the better type of student was soon recognized as an excellent teacher. In his latter years he spoke well, and always concisely.

"I have always greatly regretted that he did not get a University Chair. He would have devoted himself to it, and been of immense value to the School.

"Cowan was a slow worker, and spent a very long time in meticulous examination of his cases. His industry was tireless. He showeḑ remarkable honesty in all his work and his criticism of it. He welcomed the opinion of his juniors even when it directly countered his own, and was always prepared to discuss the differences. It was our custom to write such opinions in the case sheets and initial them.
"In addition to his sterling honesty and loyalty, he was absolutely devoid of professional jealousy and would do anything to help on his juniors. Nearly all his later publications were ' joint' ones, to give the associated junior or juniors a chance.

"I shall never forget the times we had with the polygraph. In addition to Mackenzie's instrument, he and I devised a large three-lever one which was built by Kelvin and White, and ran on smoked papers. I do not think any of us enjoyed it but Cowan himself, but we did lots of work. In the wards were also investigated: (1) insulin, (2) serum treatment and pneumonia, (3) liver extract. Cowan loved charts and never wearied of them.

" He was Principal Medical Officer to the Scottish Amicable Life Assurance Society, and did most excellent work there. This work interested him greatly.

" He was only mildly interested in sport-fished and shot, and in his earlier days, played a little cricket and golf. He was also interested in philately. He was always very keen that we should all have hobbies. In fact he was always ready to advise you in any difficulty of life."

Dr. J. L. Cochrane, an H.P. of Cowan's of forty years ago, testifies to the zeal that his Chief inspired in his assistants and the loyalty and affection with which they served him. "When you served him he served you. He discussed your future and told you that although he would not give you a roving testimonial he would always write what he thought of you for any appointment you applied for. A grand Chief!"

The original Cardiac Club owed much to Cowan's enthusiasm. As a physician he was already ripe in wisdom and experience, and had the youthful enthusiasm to practise and master the newer methods of cardiovascular investigation.

In spite of his natural reserve and a certain shyness Cowan became a trusted friend of all of us. Anything like push or self-advertisement was abhorrent to him and his only ambition was to search out and teach the truth.

The Cardiac Club were lucky to have him at its inception and the British Cardiac Society benefited by his wise and steady counsel.

W. E. HuME. 


\section{SOME CARDIOLOGICAL CONTRIBUTIONS TO MEDICAL JOURNALS}

BY

\section{JOHN COWAN}

On the presystolic murmur. Glas. med. J. (1898), 11, 166

A case of acute endocarditis. Trans. Path. Clin. Soc. (1899), 7, 237.

Notes on empyemata in childhood. Glas. Hosp. Rep. (1900), 314

On obstruction of the coronary arteries. Trans. Path. Clin. Soc. (1902), 9, 49.

Fatty degeneration of the myocardium. J. Path. (1902), 8, 177.

The heart in acute disease. Ibid. (1903), 9, 87.

The fibroses of the heart. Ibid. (1903), 9, 209.

(with A. R. Ferguson): Five cases of congenital heart disease. Lancet (1903), $2,952$.

The cardiac muscle. Edinb. med. J. (1904), 127.

The influence of the acute infections upon the arteries. Glas. med. J. (1906), 66, 88.

On anæmia with enlargement of the spleen. Quart. J. med. (1907), 1, 11.

(with L. Storey): the bruit de Roger. Glas. med. J. (1909), 72, 425.

(with D. Macdonald and R. J. Binning): The venous pulse in paroxysmal tachycardia. Quart.J. med. (1909), $2,146$.

(with J. Macleod and A. R. Paterson): A case of partial heart block. Ibid. (1910), 3, 115

(with W. T. Ritchie): Coupled rhythms of the heart. Ibid. (1910), 4, 55.

(with G. B. Fleming and A. M. Kennedy): Heart block and nodal rhythm in the acute infections. Lancet (1912), 1, 277. (with G. B. Fleming): The association between mitral stenosis and renal fibrosis. Quart. J. med. (1912), 5, 309.

Diseases of the heart. 1st ed. Arnold, London. American ed. Lea and Febiger, Philadelphia and New York.

Auricular flutter. Glas. med. J. (1914), 1, 128.

(with D. Macdonald): Chronic valvular disease of the heart. Ibid. (1914), 1, 12.

(with A. W. Harrington): A case of patent ductus arteriosus. Ibid. (1914), 1, 101.

(with W. T. Ritchie): The duration of ventricular systole. Lancet (1920), 2, 743.

(with J. K. Rennie): Syphilis of the heart. Brit. med. J. (1921), 2, 184

(with J. C. Bramwell): The clinical aspect of bundle branch block. Quart. J. med. (1925), 19, 95.

The causes of auricular fibrillation. Ibid. (1929), 22 , 237.

(with J. S. Faulds): Syphilis of the heart and aorta. Brit. med. J. (1929), 2, 285.

St. Cyres lectures. The fibroses of the heart. Lancet (1930), 2, 1.

Some observations on angina pectoris. Brit. med. $J$. (1931), 1, 879.

(with W. T. Ritchie): Diseases of the heart. 3rd ed. London (1935).

The prognosis after infarct of the heart. Lancet (1936), 1, 356.

Some disturbances of the rhythm of the heart. Brit. Heart J. (1939), $1,3$. 